\title{
STAN ZDROWIA I UMIERALNOŚĆ JAKO DETERMINANTY PROCESU DEPOPULACJI - ANALIZA NA PRZYKŁADZIE WOJEWÓDZTWA ŁÓDZKIEGO
}

\begin{abstract}
Abstrakt: Praca dotyczy oceny stanu zdrowia i umieralności województwa łódzkiego na tle sytuacji ogólnopolskiej oraz województw o najlepszych wskaźnikach trwania życia. Do analizy wykorzystano metodę dekompozycji różnic w trwaniu życia według płci i grup wieku. Zastosowana metoda pozwoliła na identyfikację grup wieku, w których zmiany w umieralności miały największy wpływ na poziom parametru e.. Podjęte zagadnienie ma istotne znaczenie w świetle obserwowanej od lat depopulacji województwa łódzkiego.

Słowa kluczowe: trwanie życia, metoda dekompozycji, województwo łódzkie.
\end{abstract}

\section{HEALTH STATUS AND MORTALITY AS DETERMINANTS OF DEPOPULATION: A CASE STUDY OF ŁÓDŹ VOIVODESHIP}

\begin{abstract}
The author have presented an assessment of health status and mortality data for the Łódź Voivodeship against these for the whole of Poland and the voivodeships with the highest life expectancy indicators. The analysis draws on decomposition of changes in life expectancy by sex and age group. This method allowed for the identification of those age groups in which changes in mortality had the greatest influence on the eo parameter level. The study is important for the Łódź Voivodeship depopulation problem, observed since many years.
\end{abstract}

Keywords: life expectancy, decomposition method, Łódź Voivodeship.

\section{WPROWADZENIE}

Stan zdrowia i umieralność są ważnymi składowymi procesów demograficznych zachodzących w populacji. Relacja pomiędzy liczbami urodzeń żywych i zgonów jest miarą przyrostu naturalnego oraz stanowi podstawę biologicznych prognoz populacyjnych. Poprawa $\mathrm{w}$ stanie zdrowia, widoczna w obniżeniu umieralności niemowląt, osób młodych i w średnim wieku, przekłada się na stan i strukturę populacji w danym regionie. Te zmiany w umieralności i wydłużanie trwania życia przyczyniają się więc do zahamowania procesu depopulacji. Zakłada się także, iż wydłużeniu trwania życia towarzyszy ogólna poprawa stanu zdrowia.

Należy podkreślić, że zdrowie rozumiane jest nie tylko w ujęciu biomedycznym jako brak chorób i niepełnosprawności, lecz także jako wartość i zasób w wymiarze indywidualnym i społecznym, co odpowiada ujęciu biopsychospołecznemu. Dobry stan zdrowia jest ważnym zasobem umożliwiającym rozwój indywidualny i społeczny, który pozwala jednostce na odgrywanie ról i zadań stosownie do wieku, rozwijanie zdolności oraz umożliwia jej osiągać określony poziom życia. Stan zdrowia populacji ma bardzo duże znaczenie (na poziomie mikro i makro) dla systemu finansów publicznych oraz wydatków gospodarstw domowych. Jest też czynnikiem wzrostu i rozwoju gospodarczego, który przyczynia się do wytwarzania dóbr materialnych i niematerialnych, a także rozwoju kultury i sztuki. Jednocześnie inwestycje $\mathrm{w}$ tak rozumiane zdrowie populacji wpływają na pomnożenie kapitału ludzkiego oraz wzrost gospodarczy i dobrobyt społeczny. Dobry stan zdrowia i długie życie mieszkańców tworzą zatem potencjał demograficzny, społeczny oraz ekonomiczny danego regionu i mogą być jednym z czynników przyczyniających się do pozostawania ludności na danym terenie oraz przyciągających nowych mieszkańców w ruchach migracyjnych.

W pracy analizowano województwo lódzkie, które od początku lat 1990. charakteryzuje się najniższym 
w Polsce poziomem dynamiki demograficznej i stałym spadkiem liczby ludności, spowodowanym zarówno ubytkiem naturalnym, jak i ujemnym saldem migracji. O ile w 1995 r. na jeden zgon w tym województwie przypadało 0,81 urodzeń, to $\mathrm{w} 2000 \mathrm{r}$. było to 0,73 (Rocznik demograficzny 2001), a w 2015 r. - już 0,71 (Rocznik demograficzny 2016); w tych samych latach wskaźnik ten dla Polski wynosił odpowiednio: 1,12, 1,02, 0,94. W latach 2000-2015 liczba ludności w województwie łódzkim zmniejszyła się o blisko 150 tys., więcej niż o 5\%. Jednocześnie województwo to cechuje się jednym z najniższych poziomów współczynnika dzietności i najwyższym poziomem umieralności.

Celem pracy była analiza stanu zdrowia i umieralności w województwie łódzkim od początku lat 1990. na tle sytuacji ogólnopolskiej oraz województw o najwyższych wskaźnikach trwania życia.

\section{ZAKRES I METODA ANALIZY}

Do analizy umieralności w województwie łódzkim na tle Polski i wybranych województw (posiadających najkorzystniejsze wskaźniki umieralności) zastosowano parametr tablic trwania życia $e_{0}$. Wykorzystano przy tym pełne tablice trwania życia dla Polski i województw według płci, opracowane przez Główny Urząd Statystyczny w Warszawie.

Do analizy zmian w umieralności wykorzystano metodę dekompozycji różnic w trwaniu życia według płci i grup wieku. Dekompozycja różnic w trwaniu życia $e_{0} \mathrm{~W}$ województwie łódzkim była przeprowadzona dla całego okresu objętego analizą w podziale na podokresy: 1990-2000 i 2000-2015.

Zastosowana metoda analizy pozwoliła na identyfikację grup wieku, w których zmiany w umieralności miały największy wpływ na poziom parametru $e_{0}$. W metodzie tej wykorzystuje się bowiem fakt, że wartość parametru eo zależy od poziomu umieralności $\mathrm{w}$ poszczególnych grupach wieku. Zaobserwowane różnice w długości trwania życia dla dwóch okresów (dwóch populacji) były efektem zmian w umieralności, które zaszły w każdej z grup wieku. Są dwa podejścia do dekompozycji różnic w przeciętnym trwaniu życia: $1^{\circ}$ - traktujące wiek, jako zmienną ciągłą (Keyfitz 1977, Pollard 1982) oraz $2^{\circ}$ - jako zmienną skokową (Arriaga 1984, Andreev i in. 2003). W prezentowanej analizie zostało wykorzystane podejście dyskretne, które w literaturze polskiej zostało opisane m.in. przez W. Wróblewską (2006).
W tej metodzie dekompozycji całkowity wpływ zmian w umieralności w grupie wieku od $x$ do $x+i$ lat na poziom oczekiwanego trwania życia noworodka jest wyznaczany według wzoru:

$$
{ }_{i} \Delta_{x}=\frac{l_{x}^{t}}{l_{o}^{t}}\left({ }_{i} e_{x}^{t+n}-{ }_{i} e_{x}^{t}\right)+\frac{T_{x+i}^{t+n}}{l_{0}^{t}}\left(\frac{l_{x}^{t}}{l_{x}^{t+n}}-\frac{l_{x+i}^{t}}{l_{x+i}^{t+n}}\right),
$$

gdzie $l_{x}, T_{x}$ są parametrami tablic trwania życia: $l_{x}-$ liczba osób dożywających wieku $x$; $T_{x}$ - łączna liczba lat do przeżycia, jaką mają osoby w wieku $x$ ukończonych lat; $x$ - wiek początkowy w grupie wieku o interwale $i ; e_{i} e_{x}$-przeciętne trwanie życia osoby $\mathrm{w}$ wieku $x$-lat w interwale wieku $i ; t$ - początkowy rok obserwacji; $t+n-$ końcowy rok obserwacji.

\section{ZMIANY W TRWANIU ŻYCIA}

Porównanie poziomu trwania życia $\mathrm{w}$ województwie łódzkim i w innych województwach oraz w Polsce ogółem wypada zdecydowanie niekorzystnie dla tego województwa. Warto podkreślić, że na początku lat 90. XX w. przeciętne dalsze trwanie życia noworodka $\left(e_{0}\right)$ w województwie łódzkim było tylko nieznacznie niższe niż dla całej Polski (rys. 1 i 2). Jednakże stagnacja tego parametru w połowie lat 90 . oraz spadek jego wartości w latach 2005-2009 spowodowały, iż w 2015 r. trwanie życia w województwie łódzkim było na poziomie zdecydowanie niższym niż $\mathrm{w}$ pozostałych województwach. I tak, trwanie życia mężczyzn w województwie łódzkim było krótsze o ponad 3,5 roku niż w małopolskim, a trwanie życia kobiet w województwie łódzkim w porównaniu do województw przodujących pod tym względem (podlaskim i podkarpackim) - było krótsze o ponad dwa lata.

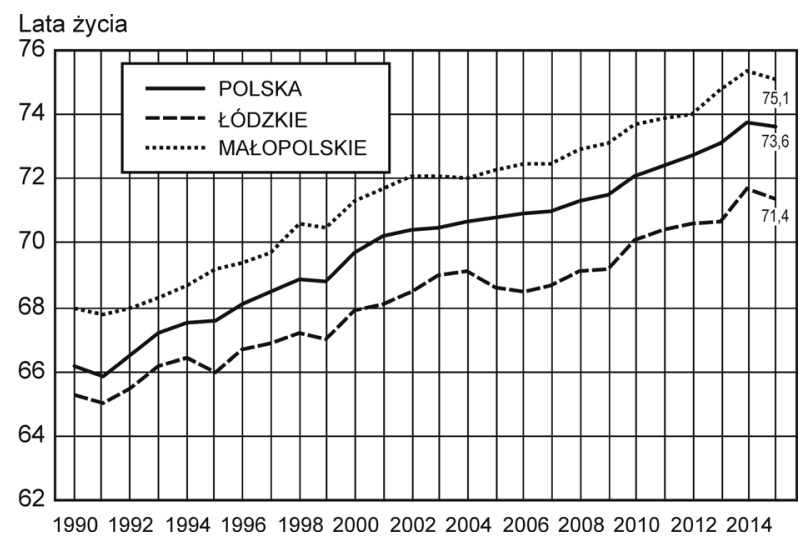

Rys. 1. Trwanie życia mężczyzn $\left(e_{0}\right)$ w województwie łódzkim w latach 1990-2015 na tle województwa o najwyższym parametrze w 2015 r. (małopolskiego) oraz dla Polski ogółem

Źródło: opracowanie własne na podstawie danych GUS 


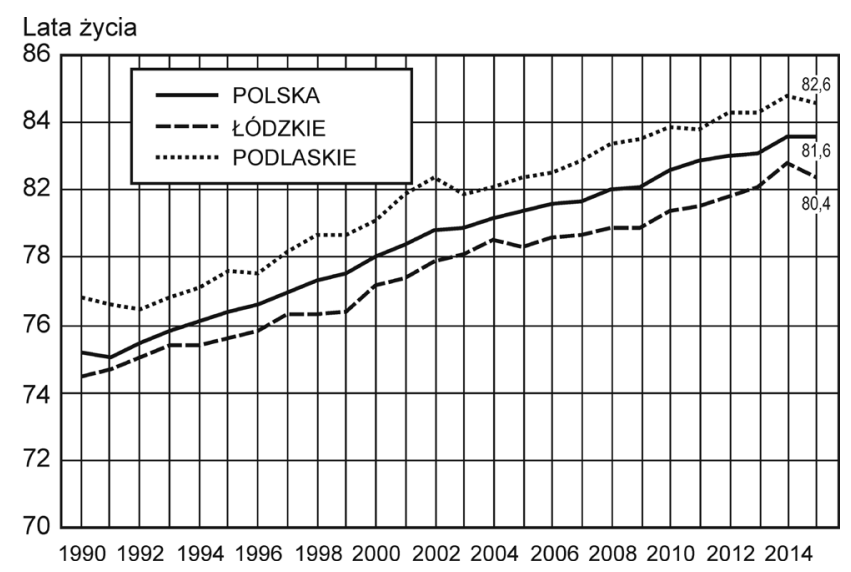

Rys. 2. Trwanie życia kobiet $\left(e_{0}\right)$ w województwie łódzkim w latach 1990-2015 na tle województwa o najwyższym parametrze w 2015 r. (podlaskiego) oraz dla Polski ogółem

Źródło: opracowanie własne na podstawie danych GUS

Porównanie długości trwania życia w województwie łódzkim w 2015 r. z okresem, w którym analogiczny poziom osiągnęły województwa o najwyższym wskaźniku $e_{0}$, pozwala na ocenę opóźnienia dla województwa łódzkiego. Dla mężczyzn jest to blisko 15 lat, a dla kobiet 10 lat opóźnienia w stosunku do innych województw.

Jednak należy zauważyć pozytywne zmiany, które dokonały się w zakresie wartości wskaźnika umieralności w województwie łódzkim - ogólny wzrost parametru $e_{0}$ i wydłużenie trwania życia. Od roku 1990 trwanie życia mężczyzn wzrosło tu o 6,1 roku (z 65,3 do 71,4 lat), a dla kobiet - o 5,9 roku (z 74,5 do 80,4 lat).

\section{DEKOMPOZYCJA ZMIANY W TRWANIU ŻYCIA W WOJEWÓDZTWIE ŁÓDZKIM W LATACH 1990-2000 ORAZ 2000-2015}

Dekompozycja odnotowanego wzrostu trwania życia w województwie łódzkim w analizowanych latach pozwala na identyfikację grup wieku, w których zmiany w umieralności miały największy wpływ na wzrost poziomu parametru $e_{0}$. Wyniki analizy dla mężczyzn i kobiet dla okresu 1990-2000 r. prezentuje rys. 3, a dla lat 2000-2015 - rys. 4.

Udziały poszczególnych grup wieku w ogólnej zmianie oczekiwanego trwania życia w danym okresie przedstawiono w latach. Dodatnie wartości, zaznaczone na wykresach w postaci słupków po prawej stronie osi, oznaczają wzrost trwania życia $e_{0}$ (w latach) wynikający $\mathrm{z}$ obniżenia umieralności $\mathrm{w}$ danej grupie wieku. Bardzo niskie poziomy (bliskie zeru) oznaczają, że w analizowanym okresie nie zaszły większe zmiany $\mathrm{w}$ umieralności $\mathrm{w}$ danej grupie wieku; nie miały więc one wpływu na zmiany parametru $e_{0}$.

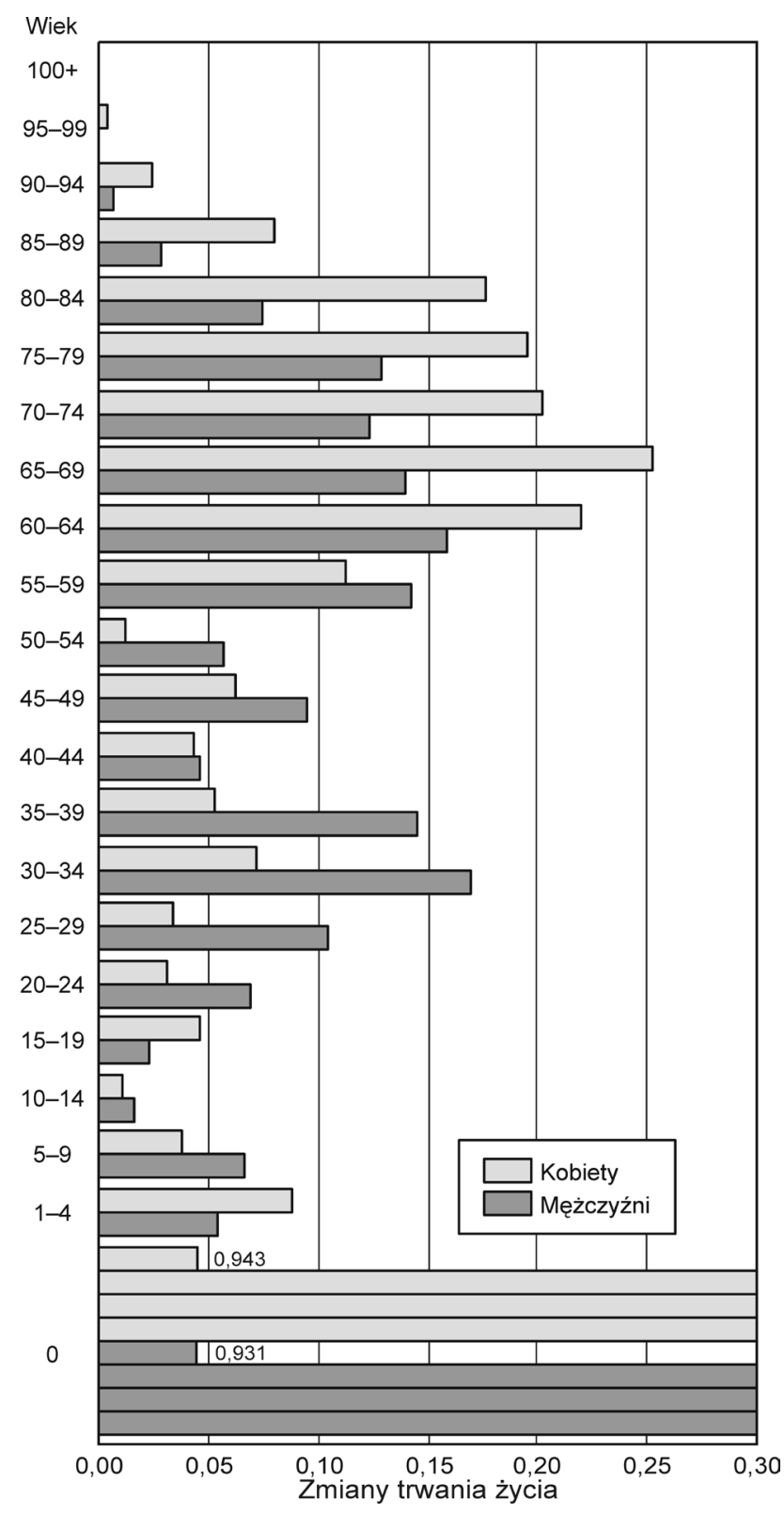

Rys. 3. Dekompozycja zmiany trwania życia mężczyzn i kobiet w województwie lódzkim w latach 1990-2000

Źródło: obliczenia własne na podstawie niepublikowanych tablic trwania życia GUS dla województw

W okresie od 1990 do 2000 r. największy wpływ na wzrost przeciętnej długości trwania życia w województwie łódzkim, wynoszący dla mężczyzn 2,6 roku i kobiet 2,7 roku, miał spadek umieralności niemowląt. Zmniejszenie umieralności niemowląt $\mathrm{w}$ tym okresie spowodowało wzrost oczekiwanego trwania życia o blisko 1 rok - około $40 \%$ ogólnej zmiany parametru $e_{0}$. 
Zmiany w umieralności, które zaszły $\mathrm{w}$ pozostałych grupach wieku miały niewielki już wpływ na wydłużenie trwania życia. Wśród mężczyzn można odnotować nieznaczną poprawę stanu zdrowia i spadek ich umieralności w wieku 25-39 lat i 55-75 lat, a wśród kobiet zaznaczyła się taka poprawa w wieku 60-85 lat. Maksymalny wzrost trwania życia, wynikający ze spadku umieralności w tych grupach wieku oscylowała wokół 0,2 roku.

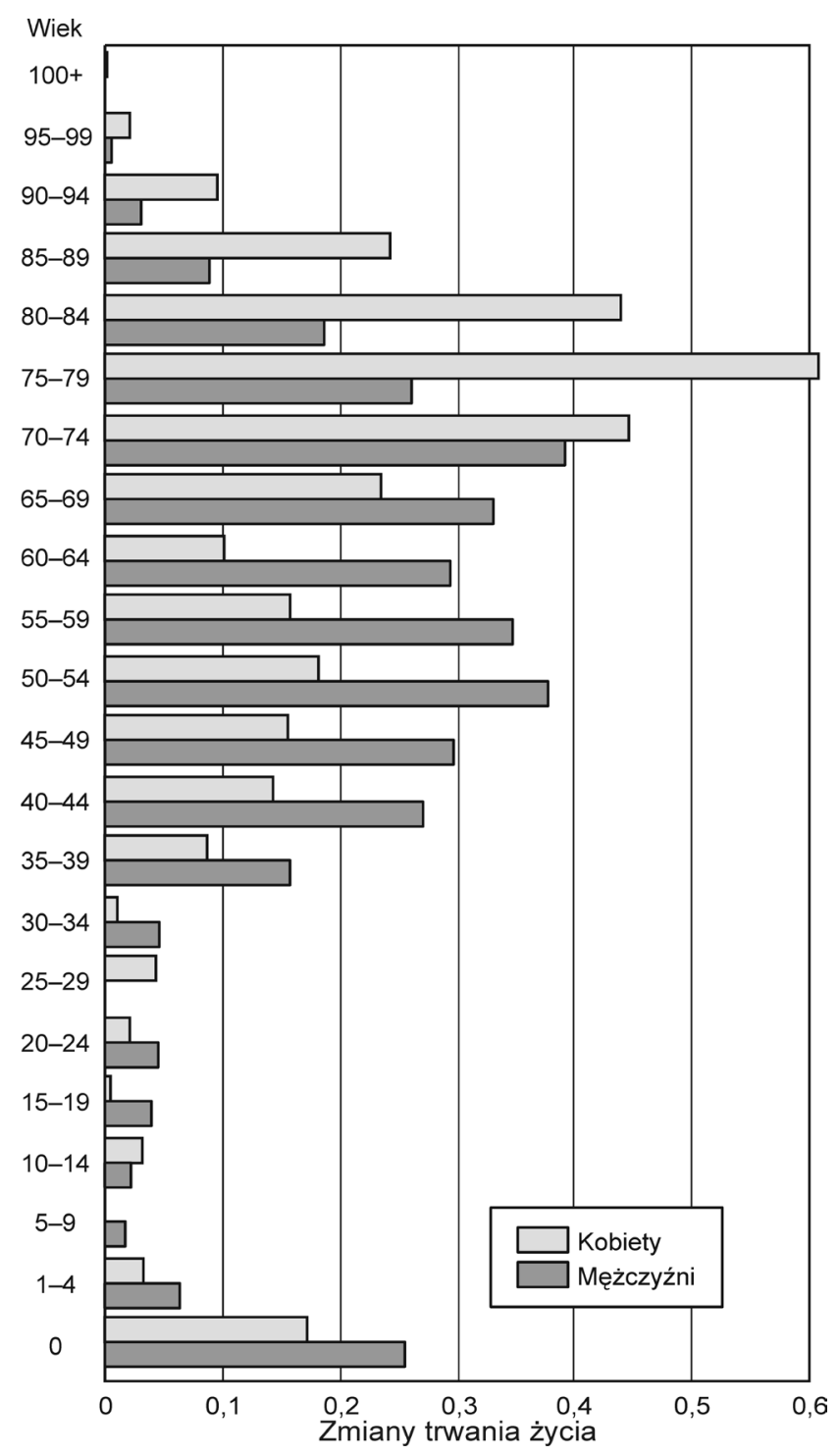

Rys. 4. Dekompozycja zmiany trwania życia mężczyzn i kobiet w województwie łódzkim w latach 2000-2015

Źródło: obliczenia własne na podstawie niepublikowanych tablic trwania życia GUS dla województw

W okresie 2000-2015 r. zmiany w umieralności niemowląt (która już wcześniej osiągnęła niski poziom) nie miały dużego wpływu na parametr $e_{0}$. Należy natomiast odnotować bardzo korzystne zmiany dotyczące wskaźnika umieralności kobiet w wieku powyżej
70 lat. Spadek ich umieralności w wieku od 70 do 84 lat (największy w grupie 75-79 lat) przełożył się na wzrost trwania życia w okresie od 2000 do 2015 r. o 1,6 roku, co stanowi $50 \%$ ogólnej zmiany parametru $e_{0}$. Dla mężczyzn odnotowany wtedy ogólny wzrost trwania życia o 3,5 roku był skutkiem spadku umieralności $\mathrm{w}$ wielu grupach wieku, głównie w wieku średnim (35-59 lat) i starszych (65-79 lat). Można zauważyć, że mężczyźni niejako „odrobili” wcześniejsze okresy braku poprawy poziomu ich umieralności, szczególnie $\mathrm{w}$ wieku średnim.

\section{DEKOMPOZYCJA RÓŻNICY TRWANIA ŻYCIA W WOJEWÓDZTWIE ŁÓDZKIM I WOJEWÓDZTWACH O NAJWYŻSZYM POZIOMIE TEGO PARAMETRU}

Interesujące jest pytanie, które grupy wieku są w największym stopniu odpowiedzialne za wciąż tak niski poziom parametrów trwania życia w województwie łódzkim $\mathrm{w}$ porównaniu $\mathrm{z}$ innymi województwami Polski. Szukaniu odpowiedzi na to pytanie posłużyła analiza dekompozycji zastosowana do tablic trwania życia dla województwa łódzkiego oraz dla województw o najwyższych w Polsce wartościach trwania życia w 2015 r. Dla mężczyzn było to województwo małopolskie, a dla kobiet - województwo podlaskie. Trwanie życia mężczyzn w województwie małopolskim w 2015 r. wynosiło 75,1 lat i przekraczało poziom dla województwa łódzkiego o prawie cztery lata (3,7 roku). Natomiast trwanie życia kobiet $\mathrm{w}$ województwie podlaskim w tymże roku równe było 82,6 lata i było ponad dwa lata (2,2 roku) dłuższe niż w analizowanym tu województwie.

Wyniki dekompozycji różnic w trwaniu życia w rozbiciu na 5-letnie grupy wieku oraz wiek niemowlęcy prezentuje rys. 5 .

Różnice w trwaniu życia mężczyzn w 2015 r. w województwie łódzkim w porównaniu do województwa (małopolskiego) z najwyższym poziomem tego parametru w Polsce można wyjaśnić wysoką nadumieralnością mężczyzn w wieku średnim. Kształt wykresu udziałów poszczególnych grup wieku w ogólnej różnicy parametru $e_{0}$ jest zbliżony do rozkładu symetrycznego, z najwyższymi wartościami dla grup wieku 45-49 lat i 50-55 lat (rys. 5). Wysoka umieralność mężczyzn w województwie łódzkim w tych dwóch grupach wieku jest odpowiedzialna za ponad 0,5 roku straty w poziomie parametru $e_{0} \mathrm{w}$ porównaniu do mężczyzn 
w województwie małopolskim. Istotne były także udziały sąsiednich grup wieku (40-44 lata i 60-64 lata), powodujące straty po około 0,2 roku oraz jeszcze kolejnych grup młodszych (25-39 lat) i starszych (65-79 lat).

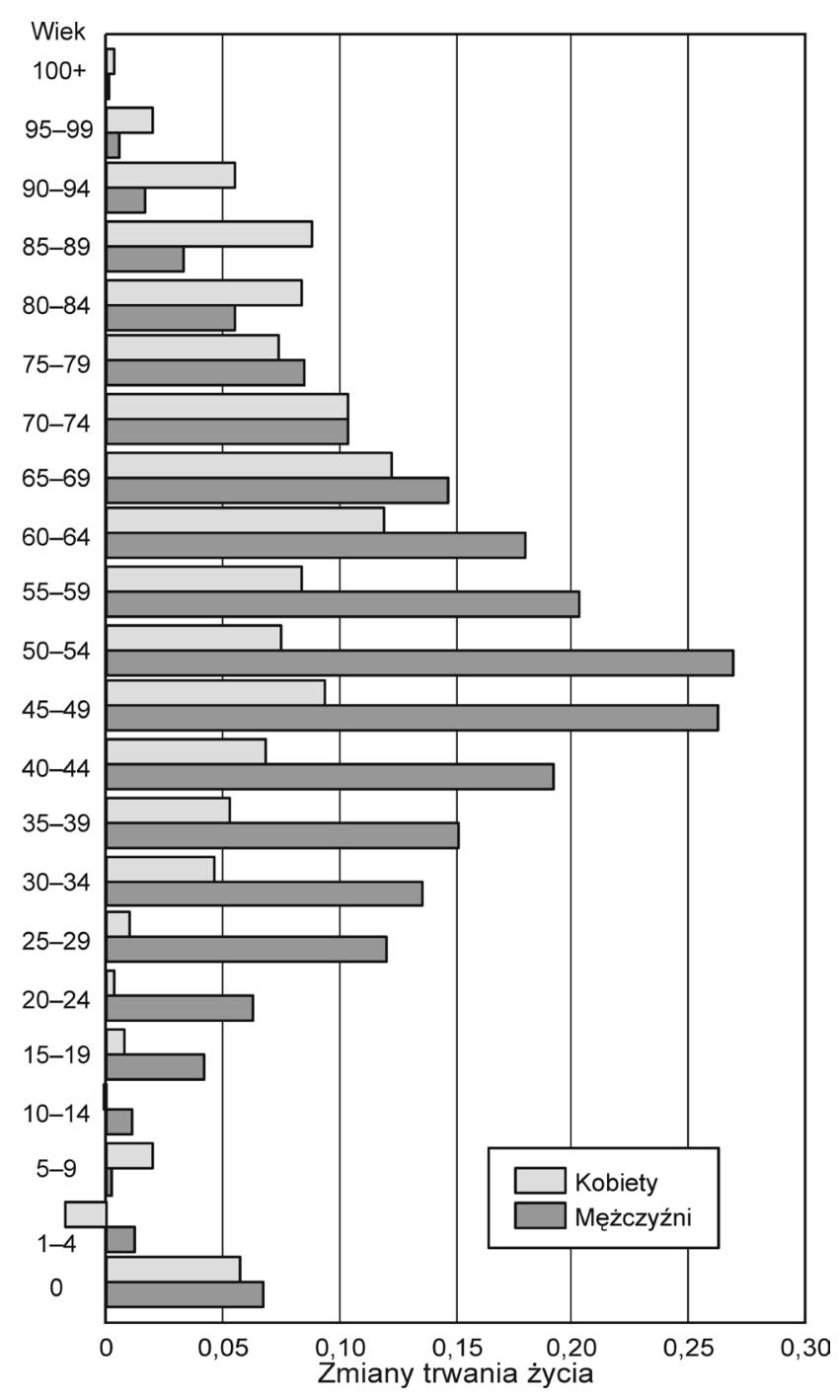

Rys. 5. Dekompozycja różnicy trwania życia w 2015 r. mężczyzn w województwach łódzkim i małopolskim oraz kobiet w łódzkim i podlaskim

Źródło: obliczenia własne na podstawie niepublikowanych tablic trwania zycia GUS dla województw

W przypadku kobiet różnice te są mniejsze i rozłożone bardziej równomiernie. Krótsze trwanie życia kobiet $\mathrm{w}$ województwie łódzkim $\mathrm{w}$ porównaniu $\mathrm{z}$ województwem podlaskim wynika $\mathrm{z}$ wyższej w łódzkim umieralności kobiet w wieku 30-89 lat, która przekłada się na obniżenie trwania życia o nie więcej niż 0,1 roku (na każdą z 5-letnich grup wieku tego przedziału). Większe różnice widzimy dla kobiet $\mathrm{w}$ wieku 60-69 lat oraz osób starszych (80-89 lat).
Nie stwierdzono różnic dla analizowanych województw (łódzkiego i podlaskiego) w poziomie umieralności dzieci i młodych kobiet w wieku do 30 lat. Dla chłopców natomiast nie ma zaś takich różnic (między łódzkim i małopolskim), tylko w przypadku grup najmłodszych - dzieci w wieku 1-10 lat. Są natomiast różnice $\mathrm{w}$ umieralności niemowląt, chłopców i dziewczynek, znowu na niekorzyść województwa łódzkiego.

\section{PODSUMOWANIE}

$\mathrm{W}$ artykule podjęto temat złej sytuacji $\mathrm{w}$ zakresie umieralności i stanu zdrowia w województwie łódzkim, która może przyczyniać się do procesu depopulacji tego regionu.

W analizowanym okresie (1990-2105) nastąpił wzrost trwania życia w województwie łódzkim o blisko sześć lat, zarówno dla mężczyzn jak i dla kobiet. Jednakże w latach 90. przyrost oczekiwanego trwania życia $e_{0}$ był wywołany przede wszystkim spadkiem umieralności niemowląt, gdyż we wszystkich pozostałych grupach wieku poprawa wartości wskaźnika umieralności była tylko nieznaczna. Dopiero po $2000 \mathrm{r}$. zaszła wyraźna poprawa co do wskaźnika umieralności mężczyzn w średnim wieku oraz kobiet $\mathrm{w}$ wieku starszym.

Uzyskane wyniki potwierdziły występowanie istotnych różnic w długości trwania życia i umieralności w województwie łódzkim w porównaniu do innych województw w Polsce. Wspomniany wyżej spadek umieralności mężczyzn i kobiet w tym województwie był mniejszy niż w innych województwach, a notowane opóźnienie $\mathrm{w}$ stosunku do tych o najdłuższym trwaniu życia w Polsce utrzymuje się na poziomie prawie 15 lat dla mężczyzn i 10 lat dla kobiet. Najważniejszym czynnikiem niskiego poziomu parametru trwania życia mężczyzn w województwie łódzkim jest znaczna tam nadumieralność mężczyzn w wieku śred$\operatorname{nim}(40-59$ lat).

Oszacowania czasowego trwania życia $\left(e_{0-75}\right)$ dla województw w latach 1991-2010 oraz dekompozycja zmiany $\mathrm{w}$ poziomie tego parametru ze względu na umieralność z przyczyn zależnych od leczenia i prewencji pokazały także niekorzystną sytuację $\mathrm{w}$ regionie lódzkim w zakresie umieralności przedwczesnej (Wróblewska 2015). Łódzkie należy do województw, gdzie trwanie życia od urodzenia do wieku 75 lat należy do najkrótszych w Polsce. W roku 2010 w województwie łódzkim mężczyźni przeżywali średnio tylko 
66,2 lat w tym przedziale wieku, a kobiety - 71,2. W województwach o najlepszych wskaźnikach wartości te były o ponad dwa lata wyższe dla mężczyzn i o ponad rok dla kobiet. Ponadto poprawa stanu zdrowia i zmniejszenie umieralności przedwczesnej w województwie łódzkim następuje wolniej, niż w innych regionach kraju (Wróblewska 2015).

Wyniki analiz przedstawione w pracy Sytuacja zdrowotna ludności Polski (Wojtyniak, Goryński 2016) wykazały, że wysoka umieralność ludności w województwie łódzkim łączy się z występowaniem określonych chorób. Do przyczyn zgonów, z powodu których umieralność w tym województwie należy do najwyższych w Polsce, należą: choroby układu trawiennego, choroby wątroby i marskość wątroby, choroby naczyń mózgowych, nowotwory tchawicy, oskrzela i płuca, a także przyczyny zewnętrzne.

Uzyskane wyniki świadczą o tym, iż wśród mężczyzn $\mathrm{w}$ średnim wieku $\mathrm{w}$ województwie lódzkim wciąż istnieją duże potencjalne możliwości poprawy stanu zdrowia i spadku umieralności, powstałe w wyniku regresu obserwowanego w latach wcześniejszych. Można mieć nadzieję, iż w najbliższych latach będzie następować przesuwanie się korzystnych zmian notowanych w zakresie wskaźników umieralności mężczyzn także i na starsze grupy wieku, tak jak to dotyczy od kilkunastu lat żeńskiej populacji tego województwa.

Ważnym czynnikiem, który może sprzyjać poprawie stanu zdrowia jest rozwój ekonomiczny i społeczny. Jak wykazało badanie terytorialnego zróżnicowania umieralności w Polsce, istotne znaczenie dla wyjaśniania występujących różnic $\mathrm{w}$ przedwczesnej umieralności miały takie czynniki, jak udział osób z wyższym wykształceniem oraz stopień deprywacji mieszkańców, a nieistotne wręcz były zasoby infrastruktury w zakresie ochrony zdrowia (Wróblewska 2017).

\section{BIBLIOGRAFIA}

Andreev E., Nolte E., Shkolnikov V., Varavikova E., McKee M., 2003, The evolving pattern of avoidable mortality in Russia, „International Journal of Epidemiology”, 32, s. 437-446.

Arriaga E., 1984, Measuring and explaining the change in life expectancies, „Demography”, 21, 1.

Keyfitz N., 1977, Applied Mathematical Demography. New York, Wiley.

Pollard J.H., 1982, The expectation of life and its relationship to mortality, , Journal of the Institute of Actuaries”, 109.

Rocznik demograficzny 2000, 2001, GUS, Warszawa.

Rocznik demograficzny 2015, 2016, GUS, Warszawa.

Wojtyniak B., Goryński P. (red.), 2016, Sytuacja zdrowotna ludności Polski i jej uwarunkowania, Narodowy Instytut Zdrowia Publicznego - Państwowy Zakład Higieny, Warszawa.

Wróblewska W., 2006, Analiza umieralności $w$ Polsce $w$ latach 1970-2003. Dekompozycja zmian w oczekiwanym trwaniu życia noworodka, „Studia Demograficzne”, 1(149).

Wróblewska W., 2015, Zmiany umieralności według przyczyn zgonów w przekroju wojewódzkim, „Wiadomości Statystyczne”, 11.

Wróblewska W., 2017, Territorial variation in mortality from causes amenable to medical care in Poland, „Annals of Agricultural and Environmental Medicine", doi: 10.5604/12321966.1233557.

Artykuł wpłyną: 11 lipca 2017

Zaakceptowano do druku: 8 listopada 2017 